\title{
Enlightenment dilemmas: nationalism and war in Rudolph Zacharias Becker's Mildheimisches Liederbuch (1799/1815)
}

Book or Report Section

Accepted Version

Pilsworth, E. (2020) Enlightenment dilemmas: nationalism and war in Rudolph Zacharias Becker's Mildheimisches Liederbuch (1799/1815). In: Nationalism before the nation. Inclusion, exclusion, and self-definition. Brill, Leiden. ISBN 9789004366831 Available at http://centaur.reading.ac.uk/79635/

It is advisable to refer to the publisher's version if you intend to cite from the work. See Guidance on citing.

Publisher: Brill

All outputs in CentAUR are protected by Intellectual Property Rights law, including copyright law. Copyright and IPR is retained by the creators or other copyright holders. Terms and conditions for use of this material are defined in 
the End User Agreement.

www.reading.ac.uk/centaur

\section{CentAUR}

Central Archive at the University of Reading

Reading's research outputs online 
Enlightenment Dilemmas: Nationalism and War in Rudolph Zacharias Becker's Mildheimisches Liederbuch (1799/1815)

\section{Ellen Pilsworth, University of Reading}

\section{$<$ L1 $>$ Abstract}

This chapter explores the moral dilemmas encountered by the Enlightenment writer and pedagaogue Rudolph Zacharias Becker around the concepts of nationalism and war. His meticulous selection and adaptation of texts for the two editions of his Mildheimisches Liederbuch (an originally pedagogical work designed to teach peasants more Enlightened ways of thinking) reveal the issues of war and nationalism to have been greatly troubling for him, yet also, unfortunately, unavoidable. While the first edition of Mildheimisches Liederbuch in 1799 treated war as a moral problem, the second edition in 1815 contained a great many new songs proclaiming the anti-French and pro-war sentiments that had arisen during the Wars of Liberation, even though his personal memoir from this period argued for tolerance and respect of the French. Why, then, did he include this anti-French material in the 1815 collection? I interpret Becker's choice to include pro-war texts with which he did not agree as an attempt to respect freedom of different political opinions, rather than to censor and control them, in the aftermath of Napoleonic occupation.

Keywords: Volksaufklärung, Wars of Liberation, Rudolph Zacharias Becker, Nationalism, Christian Friedrich Daniel Schubart, Pacifism

<L1> Introduction: Nationalism and War-a Slippery Slope 
By way of introduction to this chapter, I would like to examine a short text by someone renowned for his poetry of protest and social criticism, Christian Friedrich Schubart, entitled "Der Patriot und der Weltbürger" [the patriot and the cosmopolitan; 1774]. It depicts an argument between two men about their relationship to their fatherland. Brimming with emotion, the patriot begins by exclaiming "Wie lieb ich dich, mein Vaterland, / Wo ich den ersten Odem zog, / und frische Lüfte atmete; Wie lieb ich dich! Wie lieb ich dich!” [how I love you, my fatherland, where I drew my first breath, where I breathed fresh air, how I love you! How I love you!; Schubart, 284]. The cosmopolitan replies more coolly, whilst taking a pinch of tobacco and smirking: "Was Vaterland? - Haha, ha, ha! / Mir ist, weil ich weit klüger bin, / Die ganze Welt mein Vaterland. / Wo für mich Brot und Ehre ist, / Da ist mein Vaterland" [Pah! Fatherland? Haha ha ha! Because I am far cleverer, the whole world is my fatherland. Wherever there is bread and honour for me, that's my fatherland; Schubart 285]. The poem's narrator certainly encourages us to sympathise with the first of the two speakers: he calls him 'ein deutscher Biedermann' [a good German citizen], and comments in parentheses after the patriot's emotive, tearful display, "Oft weint ich in der Mitternacht / Auch solche Tränen; Gott, du weißt's!" [I too have often cried such tears at the midnight hour, God knows!; Schubart 284]. And yet the final stanza causes us to lose respect for the poem's narrator, and for the patriot as well. The "good German citizen" hurls abuse at the cosmopolitan, insulting his mother, accusing him of incest, and likening him to cow or a pig:

So schlägst du mit geballter Faust

Die eigene Mutter, die dich tränkte,

Ins Angesicht? — Undankbarer,

Hat jene Dirne dich gesäugt,

Der du die geilen Lippen küssest? -

Fleuch hin zur Krippe, draus du frißt, 
Und nenne sie dein Vaterland! -

[So! You punch your own mother, who nursed you, in the face? You ungrateful wretch.

Were you nursed by that prostitute whose lascivious lips you kissed? Run off back to your feeding trough and call that your fatherland!; Schubart 285.]

The poem ends there. Michaela Wirtz identifies the poem's narrator as Schubart himself, seeing it as evidence that he "[stellt] den Patrioten über den 'kalten' Weltbürger" [places the the patriot above the cosmopolitan; Wirtz 18], but I would argue that this poem is rather ironic in fact. The dissonance is simply too great between the loving and emotional tears of the patriot (and the narrator), and the angry abusive tirade that erupts from him in the final verse. The fact that Schubart leaves this angry outburst uncommented suggests a kind of embarrassment on the behalf of the poem's narrator: though he was happy to side with the patriot when expressing his tears of patriotic love, he does not support him in abusing the cosmopolitan at the end. As Wirtz also shows, Schubart was by no means blinded by patriotism in reality, but rather embraced the onset of the French Revolution, and was actually pleased to see the Alsace becoming a part of the French Republic (Wirtz 18), and so I think we must read this poem's superficially pro-nationalist message as heavily tongue-incheek.

Two ideas can be drawn from this poem which set the scene for my analysis of Becker's work, which is the main focus of this chapter. First of all, it illustrates the late eighteenth-century debate between nationalistic patriotism on the one hand, and Enlightened cosmopolitanism on the other hand. While the narrator of Schubart's poem identifies with the nationalistic patriot, also stressing his German identity by calling him "der Deutsche" (285, emphasis in original), I would argue that the poem overall makes fun of this figure by presenting both his positive and negative emotional outbursts as extreme, irrational, and fundamentally un-Enlightened. The poem demonstrates that nationalism was not only seen at 
this time as a productive ideology for political progress, but also as the very opposite of that-as a hindrance to more civilised, co-operative and progressive ways of running a nation. We will see in Becker's works that the idea of nationalism conflicted sharply with his model for Enlightenment overall, as I discuss further below.

The second message of this poem is the implication that this kind of emotional nationalism never remains a pure idea, but that it inevitably leads to physical conflict and war. The fact that the poem breaks off after the patriot's abusive tirade suggests that the dialogue is over, and could even imply that the two men have resorted to a fist fight. It certainly shows that dialogue is impossible when one of the speakers is an ideologue who cannot tolerate an opinion different to his own. When negotiations fail, war is the last resort, and its purpose is always injuring (see Scarry 63). This poem, then, demonstrates subtly the path from nationalism to warfare, by showing nationalism as a fanatic ideology that dooms negotiations and potentially leads to violence as the only remaining means of settling disputes. Having established that some in the eighteenth century saw the path from nationalism to war as a slippery slope, and viewed nationalism as a hindrance to Enlightenment progress,${ }^{1}$ let us now turn to the main subject of this chapter: Rudolph Zacharias Becker.

\section{$<$ L1 $>$ Becker as Enlightenment Activist and Early Pacifist}

Rudolph Zacharias Becker (1752-1822) was a social activist, public educator, and publicist (Tölle II), rather than a poet as such, and has mostly been studied within the context of

\footnotetext{
${ }^{1}$ See, for example Blitz, pp. 200-01 for an analysis of the debate between Lessing and Gleim, and pp. 191-94 for an exploration of the debate between Moser and Ortmann on the distinctions between patriotism and xenophobia ("Nationalhaß”). See also Pilsworth 61-62.
} 
Volksaufklärung. ${ }^{2}$ All of Becker's writings pursue the goal of making Enlightenment thought accessible to the poor and uneducated, with the ultimate aim of improving German society, both morally and economically, from the bottom up. He first outlined his ideas in 1785 , in an essay entitled "Versuch über die Aufklärung des Landmannes" [on the Enlightenment of the common man]. Here, he explains that the goal of true Enlightenment should be to enable people to fulfil their natural human inclinations for self improvement; to become "stufenweise immer edler, glückseliger, der Unsterblichkeit würdiger, und der Gottheit ähnlicher" [increasingly nobler, happier, more worthy of eternal life, and closer to God; "Versuch" 116-17]. He called this intrinsic human drive for self-improvement "Perfektibilität" (perfectibility) or "Vervollkommnung" (perfectioning; see Freytag 189-304; Tölle 257-64), and saw it as the way to bring about lasting social change on a broad scale. Becker believed that if the poorest and most oppressed people in society were only encouraged to pursue this goal, and, more importantly, were allowed to do so by those in power, then the necessary improvements to the prevailing social, political, and economic systems would take care of themselves:

Denn offenbar ist die Haupttriebfeder der Entwickelung des Menschen, der ihm eigenthümliche Hang zur Vervollkommenung [sic], in den meisten Staatsverfassungen, entweder noch gar nicht angespannt, oder falsch gerichtet: und der Kampf der Vernunft mit der Thorheit, des Lichts mit der Finsternis, ist noch lange nicht entschieden.

[For it is obvious that the primary drive behind human development, that is, man's own innate desire for perfection and self-fulfillment, is either not considered by most state constitutions, or it is misgoverned. The battle of Reason against stupidity, and of light against darkness is far from over; "Versuch" 109.]

2 This term refers to a movement during the Enlightenment period which broadly aimed to educate the lower classes of society, though with a variety of different objectives; see Böning et al.. 
Though Becker still fundamentally supported the authority of the aristocracy, he was not afraid to argue that rulers should take a more active role in encouraging their subjects to improve their own lives and livelihoods. He was, however, categorically opposed to revolution of the kind seen in France, instead believing that instigating gradual improvements from the bottom up was the way to secure a more egalitarian society.

The issues of war and nationalism presented Becker with a dilemma because they conflicted with his philosophy of Enlightenment, which is founded on an awareness of humanity's place within the universe, and under God's rule. He stresses the need for educating the poor not only for their own sake, but for the benefit of society as a whole: "Wer aber seinen Blick von seinen kleinen persönlichen Angelegenheiten bis zum großen Weltall erhebt, und die rechte Stelle kennt, die der Mensch in demselben bekleidet, wird gewiss die Aufklärung des Volks für eins der gemeinnüzigsten und rühmlichsten Geschäfte halten” [anybody who lifts up his gaze from his own petty, personal affairs, and looks into the great universe, correctly recognizing the space that man takes up within it, will surely see that the Enlightenment of the common man is one of the worthiest pursuits for the benefit of the greater good; Becker, "Versuch" 109]. Becker's holistic approach to humanity-founded on the idea of Christian equality and brotherhood—-does not leave much space for private selfinterest or nationalism.

In 1795, Kant would cite the moral arguments against war ever being legal in his essay "Zum ewigen Frieden" [On Perpetual Peace; 441], and we can see similar lines of argumentation in Becker's works of this decade. For him, it is difficult to see how war and bloodshed could ever be justified as means to a truly Enlightened end. Indeed, some of Becker's writings mark him out as an early pacifist figure, although this term is not normally applied to writers and thinkers of this period. On the whole, nationalism and war conflicted 
with Becker's goals for social progress, as we will see in more detail by examining some of his pedagogical texts.

<L1> Becker's “Mildheim System”: A Programme for Enlightenment

In order to spread his ideas for Enlightenment to his poor and mostly illiterate target audience, Becker developed a series of pedagogical works meant for communal use in rural communities. The first of these was the novel-like Noth- und Hülfsbüchlein für Bauersleute [Guidebook for Farmers; 1788]: an educational "Volksbuch" [chapbook] which he had already outlined in his essay, "Versuch über die Aufklärung des Landmannes" (56). Set in the fictional village of Mildheim, the novel tells the story of how the villagers of Mildheim benefitted from reading a textbook called "das Noth- und Hülfsbüchlein," which itself is inserted into the frame narrative between chapters fourteen and fifteen. The textbook teaches each of its lessons through fictional stories, character monologues and dialogues, and a series of delightful woodcuts which were included to entertain illiterate users of the book. (The work was designed for reading aloud.)

The success of Noth- und Hülfsbüchlein für Bauersleute was tremendous. As many as 100,000 copies were sold between June 1788 and February 1791, with the total number of copies sold rising to 130,000 by March 1798 (Tölle 241). Siegert describes the work as the most widely disseminated secular book in Germany around 1800 (476). Because of its great success, Becker issued Part Two of Noth- und Hülfsbüchlein in 1798, and followed this publication with more works for communal use alongside it: Das Fragebuch für Lehrer [Question book for Teachers], "Die Mildheimische Sittentafel"3 [Mildheim Table of Morals],

\footnotetext{
${ }^{3}$ See Siegert (Aufklärung 815-1) for a facsimile of the Sittentafel.
} 
and Mildheimisches Liederbuch [Mildheim Songbook]. ${ }^{4}$ Together, these works make up the "Mildheim System." All were carefully designed for their target audience, and carried the same message: that the means for agricultural, educational, medicinal, personal, and spiritual progress are available to everyone, no matter how poor you may be, if you only think positively and practically about how to bring about progressive changes in your own life. Indeed, Becker repeatedly stressed that the goal of his work was not to entertain, but rather to instruct and influence:

Die Absicht, warum ich das Noth- und Hülfsbüchlein herausgegeben habe, war nicht bloß, dem Landmanne und gemeinem [sic] Bürger ein Buch in die Hände zu liefern, das von ihm mit Nutzen und Vergnügen gelesen werden könnte: sondern zu machen, daß diese Stände durch den Gebrauch dieses Buches, und der damit in Verbindung stehenden Liedersammlung gewisse Kentnisse und Einsichten, auf welchen ihr Wohlseyn beruhet, wirklich Erlangen, und eine gewisse Art $\mathrm{zu}$ denken und $\mathrm{zu}$ handeln, die zur wahren menschlichen Glückseligkeit führt, wirklich annehmen möchten.

[The intention behind my Guidebook was not only to provide the farmer and common man with a book that he could read for his pleasure and profit, but also to ensure that by reading this book, these classes might truly acquire the knowledge and insights contained there, and in the accompanying songbook, upon which their own wellbeing depends. I hope that they should actually learn a certain new way of thinking and behaving, which will lead them to true human happiness; Fragebuch 3.]

\footnotetext{
${ }^{4}$ Later additions to this series were the pamphlet Das Friedensfest, wie solches zu Mildheim gefeiert worden [how the peace celebrations were conducted in Mildheim; 1801], and Das Mildheimische Evangelienbuch [the Mildheim book of the Gospel; 1815]. See Freytag 165.
} 
As these passages make clear, Becker was a dedicated writer and social activist, who was motivated by a powerful sense of injustice in the world in which he lived. His respect for all of humanity, regardless of wealth or social status, and his determination to improve things for the poorest and most oppressed in society, are as admirable today as they were in the eighteenth century.

Becker presented both his public mission and his theory of perfectibility as founded on his Christian principles, and it was clearly difficult for him to reconcile the ideas of nationalism and war with his social ideals, though this conflict was clearly less avoidable in 1798 than it had been a decade before. In the first Noth- und Hülfsbüchlein, from 1788, the only mention of war had appeared in chapter fifty-five: "Was Bauersleute in Kriegsnoth, auch bey Streitigkeiten und Processen zu beobachten haben" [what peasant folk have to watch out for in times of war, as well as times of dispute and legal proceedings]. Here, the narrator cited the visible improvements in warfare as evidence for human perfectibility: "Das es auf Erden immer besser wird, sieht man unter anderen auch an der Art, wie man heut zu Tage Krieg führt" [evidence for the fact that everything on Earth is constantly improving can be seen, among other things, in the way that wars are fought today; Noth- und Hülfsbüchlein 397]. By the time of Becker's publication of Part Two, however, his rose-tinted spectacles had clearly been shattered by the chaos and bloodshed of the French Revolution, and the invasion of the German lands by the quickly mobilizing French Revolutionary armies (see Birgfeld I 100-03, II 583-89). In chapter fourty-four of the later edition of Noth- und Hülfsbüchlein (1798), the narrator describes the barbarism of the warfare witnessed in Germany between 1792 and 1797, and attributes it to the failure of the Enlightenment project. He still insists, however, that if 
only people would truly improve themselves, then war would be over for good: "der Krieg wird ganz aufhören" (Noth- und Hülfsbüchlein [1798] 333-34).

In what remains of this chapter, I examine how the issues of nationalism and war are approached in the two editions of Becker's Mildheimisches Liederbuch [Mildheim Songbook], designed for use as part of the pedagogical "Mildheim System." How did Becker hope to educate his readers regarding these two ideas? I will show that the first edition of the songbook in 1799 reveals Becker wrestling with the two concepts, in view of the very real military threat now already posed to the German lands by the French Revolutionary army. By the time of the 1815 edition, after the Wars of Liberation, it seems to have become impossible for Becker to exclude nationalistic viewpoints from entering his collection. Rather than seeing this as a straightforward case of nationalistic brainwashing, however, I suggest there is a more subtle and intellectual reason for Becker's inclusion of this controversial material, as I will argue in what follows.

<L1> Nationalism and War in Mildheimisches Liederbuch (1799) and Das Friedensfest (1801)

Containing 518 songs, Mildheimisches Liederbuch ${ }^{5}$ was produced for use alongside the second edition of the Noth- und Hülfsbüchlein für Bauersleute (1798), as a further resource to underpin the same lessons. Becker sourced his material from various writers and pedagogues of the time (see Weissert 22-6 and 38-42), and only wrote a small number of poems himself, usually to fill thematic gaps, or when the topic was one he felt strongly about, such as “Justice" or "Enlightenment" (see Figure 2).

\footnotetext{
${ }^{5}$ References to Mildheimisches Liederbuch (1799) will be given as MLB; references to Mildheimisches Liederbuch (1815) will be given as MLB.2.
} 
$<$ L1 $>$ Figure 2

Table Showing the Texts Contributed by Becker in Mildheimisches Liederbuch (1799 and 1815)*

\begin{tabular}{|c|c|c|}
\hline $\begin{array}{l}\text { Number in } \\
\text { MLB (1799) }\end{array}$ & $\begin{array}{c}\text { Number in } \\
\text { MLB.2 (1815) }\end{array}$ & Subject Matter \\
\hline 17 & 38 & Water/streams \\
\hline 21 & 42 & Water/streams \\
\hline 31 & 68 & Domestic animals \\
\hline Not included & 243 & Imprisonment \\
\hline 367 & 537 & Against war \\
\hline 369 & 539 & Praising peace \\
\hline 411 & 598 & Song for a miller \\
\hline 432 & 632 & Song for a new school boy \\
\hline 446 & 650 & Song for butchers \\
\hline 462 & 671 & Song for a builder \\
\hline 467 & 677 & Song for builders \\
\hline 476 & 685 & Song for smiths \\
\hline 471 & 686 & Song for wagoners \\
\hline 487 & 714 & Song for a pastor \\
\hline 491 & 718 & Song “für Schriftsteller" [for writers] \\
\hline 426 & 720 & Praising the Enlightenment \\
\hline 496 & 733 & Justice \\
\hline
\end{tabular}

*The information in this table is derived from Häntzschel's list of contributors in Mildheimisches Liederbuch: Faksimiledruck (47*). 
Becker printed a call for contributions, designating both the thematic and formal aspects of the poetry he was hoping to include. The texts had to be easily comprehensible, avoiding figurative speech, and upholding solid moral precepts (see Becker, “An die Leser” 407). Songs were included in different sections that, taken together, covered every aspect of life, including the natural world, sickness and health, the spiritual life, childhood, domestic life, the work carried out by various trades and professions, important occasions such as weddings, births, and deaths, and social events such as festivals. Each of the songs in the Liederbuch was also paired with a lesson from the Mildheimische Sittentafel.

The songs on patriotism and war appear in the third part of Mildheimisches Liederbuch, which is under the rubric: "Der Mensch in Gesellschaft mit seines Gleichen, als Freund und Lebensgefährte, Staatsbürger und Zunftgenosse, bis zum Grabe" [man in society among his equals, as a friend and companion, a state citizen and guild member, until the grave]. The section "Vaterlandslieder" [songs for the fatherland] from pp. 214-21 contains nine songs for use at patriotic or national celebrations. They are, however, almost entirely peaceful and non-violent. For example, song 359 praises the local prince (a space is left so that the singer may insert the name of his or her local ruler), and calls for an end to hatred: “Es sterbe Haß und Neid! Es blühe Redlichkeit noch zu der Enkelzeit im Vaterland!” [may hatred and envy perish. May honesty still thrive in our fatherland, even in our grandchildren's time; MLB 216]. ${ }^{6}$ Clearly, this is an anti-revolutionary song, echoing Becker's respect for monarchical constitutions, which he saw as part of the God-given universal order. The first verse of song 361 argues similarly: “Auch wir, dem Himmel Dank! sind frey; nur sind wir's still und schlicht; bey uns ist Freyheit, nicht Geschrey, tobt und rumoret nicht' [we too are free, thank God! But we are free calmly and simply. We have freedom here, not uproar. Do

\footnotetext{
${ }^{6}$ The texts in Mildheimisches Liederbuch are presented as prose, in columns, which is why I have not indicated line breaks in my transcriptions from this work. The decision to present texts in this way was part of the work's chapbook "disguise" (see Becker, "Versuch" 130).
} 
not rage and rumble; MLB 217]. Verse 5 makes a comparison with the French Revolution more explicit: "Was soll uns Freyheits-Schwärmerey? Wir haben Freyheits-Sinn; macht mich die rothe Müze frey, wenn ich es sonst nicht bin?" [we do not need to rave about freedom, as we already have it within us. Does a red cap set me free, if I am not free already?; MLB 217]. To summarise this section, then, Becker's "patriotism" is mostly expressed as support for the aristocracy and critique of the French Revolution, but without descending into hatred of the French or an explicit call to arms against them. The only song which mentions the idea of death for the fatherland is told in the voice of a young boy, who is eager to join the army he sees passing though his village, and is willing to die for his fatherland, like his father before him, if needed (see song 364, MLB 219). There is no song which defines German national characteristics as anything that could not be seen as generic Christian attributes (honesty, goodwill, love, etc.). This kind of patriotism was acceptable to Becker: celebrating and upholding the principle of Enlightened monarchical rule, preventing violent revolution, and spreading messages of universal goodwill.

Songs on the topic of war appear in two different sections of the collection: one on "Krieg und Friede" [war and peace; MLB 221-23], and one with the title "Für den Wehrstand" [for the military; MLB 309-26]. The locations of these sections already tells us much about how Becker viewed the role of soldiers and war in society. The section entitled "Krieg und Friede" comes immediately after "Vaterlandslieder," stressing the obvious link between nationalism and war. Yet the military section appears separately, at the end of a long list of other professions ranging through farmers, various types of craftsmen, hired hands, and teachers, before turning to soldiers. The only groups to follow after soldiers are Jews and gravediggers. This placement shows the relatively low esteem with which soldiers were still held in society in 1799 , even within the lowest social class for which this work was produced. Harari has demonstrated that eighteenth-century military strategy considered common 
soldiers essentially as mindless automatons, and that this view only began to change in the early 1800s, when German armies reformed in imitation of the French models that allowed soldiers more initiative (Harari 160-77). Mildheimisches Liederbuch indirectly reflects this older suspicion of soldiers as brutal, cunning, and filled with low urges (Harari 160-61) because this is exactly the kind of behaviour that its songs oppose. It is clear that Becker still saw soldiers in this traditional way, and yet attempted to civilise them by presenting them in an idealised manner.

For example, soldier songs 501 and 502 both include statements of piety and morality that seem, frankly, too good to be true. The soldier speaker of song 501 asserts:

Daß ich des Wirthes Kind und Weib zur Unzucht nicht verführe, sey Arbeit stets mein Zeitvertreib, wenn ich bin im Quartiere: weil Nichtsthun, wie ihr alle wißt, der Anfang aller Laster ist.

[So that I do not seduce the landlord's children and wife when I am quartered, I make work my constant occupation. For idleness, as you all know, is the source of all vice; MLB 317.]

The military songs of Mildheimisches Liederbuch promote good behaviour only, and killing and death play a comparatively minor role in them. More often than not, they focus on moral behavior while soldiers are amongst civilians, rather than on life on the battlefield. None of the ten songs for soldiers include the kinds of violent and gory imagery that we are used to from the poetry of the Seven Years' War by Karsch, Gleim, et al. Song 504 does incite soldiers to fight the enemy, yet it makes sure to remind the reader that "des Feindes Blut ist Menschenblut; und Mordblut ist nicht Heldenmut" [the enemy's blood is human blood, and murderous blood is not heroic blood; MLB 320]. Previously, song 503 had explained that war is an unpleasant necessity which must be fought, however regretfully, in order to maintain and uphold justice: "Nicht jeder übet jederzeit Gerechtigkeit und Redlichkeit, man muß die 
Frevler schlagen, daß sie nichts Aergers wagen; drum giebts auf Erden Krieg, drum giebt es, leider! Krieg" [Not everyone always acts justly and honestly. We have to beat back the wicked, or they will stop at nothing. That's why there's war on Earth, that's why - alas! there's war; MLB 319.] Furthermore, song 503 reminds soldiers of their duties as fellow human beings, and as Christians: "Doch wer ein braver Krieger ist, ein braver Krieger und ein Christ, wird nicht mit Blute spielen, der kann auch menschlich fühlen, er hat ein Menschenherz, er hat ein Menschenherz" [yet he who is a good soldier and a Christian, he will not play with blood. He can feel humanely, and has a human heart, he has a human heart; MLB 319]. Within the genre of war songs, these appear surprisingly peaceable!

The soldier songs discussed above do not reflect the level of brutality that the narrator of the second part of Noth- und Hülfsbüchlein (333) head claimed to have observed in the wars fought over the 1790s. They instead maintain an idealised view of warfare as a moral institution, and of soldiers as the perfect and exemplary Christians. However, not all of the songs in the 1799 edition of Mildheimisches Liederbuch maintain this idealised view of warfare. Becker appears both to accept war as a moral necessity in times of crisis (as in the songs explored above), and also to criticise it as a human tragedy.

Appearing in the section "Für den Wehrstand," songs 506 and 510 were authored by Christian Friedrich Daniel Schubart (although his name was not included in this 1799 edition). The first of these (usually entitled "Kaplied" [Cape song]) was written to criticise the selling of German soldiers to fight for foreign armies in Africa. Becker adds a reassuring footnote explaining to the reader that such things would never happen in Germany again. ${ }^{7}$ Yet this footnote also reveals a certain anxiety about including the song at all: "Dieses Lied ist von Wirtembergischen Soldaten gesungen worden, die an die Holländer verkauft waren, und auf das Vorgebirge der guten Hoffnung geschickt wurden: welches nun in ganz

7 Wilson describes the practice of selling soldiers as "universally loathed and publicly criticised in Germany," despite being fairly widespread (Wilson 303). 
Deutschland wohl nicht mehr geschehen wird" [this song was sung by soldiers from Württemberg who were sold to the Dutch, and sent to the Cape of Good Hope, a practice which will probably never happen again in all of Germany; MLB 320]. Though Becker's need to explain his inclusion of this song may partially have resulted from its common usage by republican agitators (Schneider 294), the second text by Schubart included in this section of Mildheimisches Liederbuch as no. 510 demonstrates even more clearly Becker's uneasiness about addressing the topic of war. Schubart's poem (elsewhere entitled "Der Bettelsoldat," see Grätz 311-13) is told in the voice of a war cripple who painfully regrets his decision to join the army, and ends by entreating his listeners to avoid making the same mistake:

Ihr Söhne, bey der Krücke,

An der mein Leib sich beugt,

Bei diesem Tränenblicke,

Der sich zum Grabe neigt;

Beschwör' ich euch - ihr Söhne!

O flieht der Trommel Ton!

Und Kriegstrommetentöne:

Sonst kriegt ihr meinen Lohn.

[You sons! By the crutches that I cling to, by my tearful gaze which lowers itself to the grave. I entreat you, sons, oh! - flee the sound of the drums and the trumpets of war, or your reward will be the same as mine'; Schubart 324.]

However, the version in Mildheimisches Liederbuch adds two more verses with a caveat which must have been added by Becker (see Steinitz 456) in view of the very real threat now posed by the French Revolutionary army on German soil: 
Nur wenn dem Vaterlande ein Feind mit Krieges-Noth, und eurem Volk die Schande der Unterjochung droht:

Dann, Kinder, greift zum Schwerdte! dann schont nicht Blut, nicht Feu'r! dann reiniget die Erde von solchem Ungeheur!

[Only if an enemy approaches the fatherland in a time of war, and threatens your people with the shame of subjugation, / Then, children, reach for your sword! Then, spare neither blood, nor fire. Then, cleanse the Earth of such a monster; MLB 325.]

The aggressive, militaristic language of the final stanza contrasts entirely with Schubart's original poem, and also stands out in the section of soldier songs on the whole. Becker's decision to modify this anti-war song for inclusion in Mildheimisches Liederbuch is evidence of his significant moral dilemma on the topic of war. He was clearly both aware of its brutal, inhumane, and un-Christian nature, and yet could no longer practically banish it from his worldview, or from his song collection, in 1799. Becker's additional stanza makes room for war as a moral necessity, but only when the freedom of the nation is severely threatened (as it then was, by Napoleon's troops).

The other section containing war songs in this edition, entitled "Krieg und Friede" contains only three songs, and all of them are against war. The last of these three (song 368) is particularly intriguing. It comes from the closing chorus of Johann Adam Hiller's comic opera of 1772, Der Krieg. Eine komische Oper in drei Akten: a highly satirical depiction of warfare and military culture on the whole (with a libretto by Christian Felix Weiße featuring some poems by Carl Wilhelm Ramler, based on a play by Carlo Goldoni, La Guerra). The complete text in the opera's version has five verses (see Hiller et al. 181-82), whereas only three are included in Mildheimisches Liederbuch. This might reflect Becker's choice to eliminate verses that he deemed to be too highbrow, as one of the omitted verses refers to the 
myth of the Golden Fleece. Yet it may also be that Becker knew only this shorter version of the song, as Weiße and Hiller's opera songs frequently entered the oral tradition and became known as folksongs in their own right, without any connection to their operatic context (see Joubert). The latter possibility would imply that this anti-war song was genuinely popular at the time. Its second stanza uses the language of the pastoral to imagine a world returned to peacetime, considering the global image of "Vater-Erde" [father Earth] rather than the narrower, more usual "Vaterland":

Du [Friede] kehrst unsre Vater-Erde wieder in ein Paradies; tränkst uns mit der Milch der Heerde, wärmst uns mit der Schaafe Fließ.

[You (peace) make a paradise of our Father-Earth again. You water us with the milk of the herd and warm us with the fleece of the sheep; MLB 222.] ${ }^{8}$

The other two songs in this section for war and peace were written by Becker himself (though presented anonymously; see Figure 2), which again shows that he felt the need to engage critically with the difficult topic of war. Both of his texts are anti-war songs. In song 367, the poetic speaker cries out against war in a tragic monologue which is quite long for a Mildheimisches Liederbuch song (eleven stanzas). The poem opens with a panoramic view of the battlefield from the speaker's perspective:

Ach! was seh' ich? Weite Felder dicht von Mann und Roß bedecket; Wagen Züge durch die Wälder Meilen weit dahin gestrecket; alles in dem schönsten Glanze, überall Trompeten-Schall: eilen sie zum frohen Tanze? Feyern sie ein Freudenmahl?

[Oh, what do I see? Broad fields packed with men and horses, lines of wagons stretching miles away through the forests. Everything gleams beautifully, and

\footnotetext{
${ }^{8}$ This song is also sung by the fictional villagers of Mildheim in Becker's anti-war pamphlet, Das Friedensfest (14), discussed in more detail below.
} 
trumpet fanfares are heard all around. Are they hurrying to a joyful dance? Are they celebrating a banquet?; MLB 221.]

The poem thus uses the techniques of epic poetry (now established for patriotic war poetry by writers such as Karsch, as in her poem "Auf den Sieg bei Torgau"), in which the scene unfolds and is viewed from afar. However, Becker's speaker is deeply saddened by what he sees:

Ach! Sie rüsten sich zum Kampfe; Blut und Tod ist ihr Begehren! Bald verhüllt in schwarzem Dampfe sich der Glanz von beyden Heeren; Feld und Wald umher erbeben; Donner rollen Schlag auf Schlag, Blitze leuchten, Wolken heben sich empor, Nacht wird aus Tag.

[Alas! They are preparing for battle; desiring blood and death. Soon the glow of both armies is cloaked in black smoke. The surrounding fields and forests shake. Thunder rolls, striking again and again, lightening flashes. Clouds go up, turning the day into night; MLB 221.]

The poem's use of weather imagery here presents the war as a kind of natural disaster, like a terrible, but natural storm-again, echoing contemporary comparisons of the French Revolutionary Wars with natural disaster (E. Becker 84-85). However, Becker's battle song does not take sides, but views both (unnamed) armies neutrally as "die Streiter" [the opponents]. Rather than championing any particular political cause, this poem undermines the glory with which war is associated, by summarising the outcome of the battle in a single sentence: "einer siegt, der andre fliehet" [one wins, the other flees]. In contrast, however, the majority of the poem's remaining nine stanzas depict in great detail the suffering of the wounded, the destruction of the fields, and the moral depravity and loss of innocence that warfare brings with it. Stanza six shows frustration at the failure of the Enlightenment to put an end to such horrific acts of warfare: 
Sind dies Löwen, sind es Tieger, die aus Blutdurst sich verderben? Nein! ach! Menschen sind die Krieger, Menschen, Brüder, gleiche Erben eines Geistes hoher Würde, der vom Quell der Lieb' entspringt, und sich von des Lebens Bürde wieder auf zum Himmel schwingt.

[Are they lions, are they tigers, who destroy each other out of lust for blood? No! Alas! These warriors are people, people! They are brothers, equal heirs of the same noble dignity of spirit that springs from the fountain of love, and that returns to heaven when released of its mortal burden; MLB 221.]

Similarly, stanza eight suggests a pacifist outlook — that warfare must be for ever abandoned if mankind is to achieve its true, God-given, potential:

Krieg! o, aller Ungeheuer schrecklichstes, verlaß die Erde! Lösche dein zerstörend Feuer, daß der Mensch zum Menschen werde! Bis du gänzlich ausgerottet, schändet sein Geschlecht die Welt; ihres Schöpfers Weisheit spottet, wer dich für nothwendig halt;

[War! Oh you most terrible of all monsters, leave the Earth! Put out your destructive fire, so that humanity can become humane! Until you have been stamped out for good, the race of mankind will bring shame to the world. Whoever thinks you are necessary makes a mockery of his own Creator's wisdom; MLB 367.]

Becker presents his opposition to war as rooted in his Christian faith here. Correspondingly, the other song authored by him in this section (song 369, MLB 222) praises God for peace, and begs forgiveness on behalf of all those who fight wars. Curiously, this poem is not divided into numbered stanzas, but appears more like a dramatic monologue, or a prayer, closer to a speech than a song. Perhaps this indicates that Becker did not write the poem specifically for inclusion within Mildheimisches Liederbuch, but for another purpose 
originally. It surely seems significant, however, that Becker chose to write two poems for this section himself, when he wrote only sixteen overall for the whole 1799 edition (see Figure 2). Becker's decision to write his own pacifist poems here suggests that he felt a particular interest in the topic, and, I suggest, felt motivated by his Enlightened and Christian idealism to make a powerful case against war in this section, particularly as large-scale war with the French seemed increasingly likely.

In 1801, Becker took his anti-war activism even further, publishing a dedicated pamphlet called Das Friedensfest, wie solches zu Mildheim gefeiert worden [the peace celebration, as celebrated in Mildheim]. The foreword describes the fictional peace festivities in Mildheim as having been planned "nicht allein zum Vergnügen, sondern auch zur wahren christlichen Erbauung der Gemeinde" [not just for the people's enjoyment, but for their true Christian edification; Das Friedensfest 4]. ${ }^{9}$ As part of the event in Mildheim, Corporal Wackersinn (one of the fictional military men who has now returned from the war with France) describes the life of a soldier and the nature of warfare for the crowd of gathered villagers (16-36). He paints a terrible, gruesome picture of the slaughter on the battlefield (30-36) and recounts that one man exclaimed after a battle, while viewing the piles of bodies around him, "Brüder seht, das ist unsere heutige Arbeit! Die Menschen haben wir gemordet! Und, was hatten sie uns gethan?" [brothers, look, this was our day's work: we murdered people! And what had they done to us?; 35]. The description of soldier's work as murder is striking (see Siegert 820-21), as it presents such work as in contempt of secular law as well as God's law. Furthermore, by using the term 'brothers' and questioning the reason for the enmity between the two armies, this speaker highlights the futility of such warfare, as all men are equally deserving of life and respect. Wackersinn then reflects critically: "wer sollte es

\footnotetext{
${ }^{9}$ This might also show the influence of Kant's essay "Zum ewigen Frieden” on Becker's thinking, as Kant's text suggested that declarations of peace should not only be followed by festivals of thanks ("Dankfeste"), but also by a day of penance ("Bußtag"; Kant 443).
} 
für möglich halten, daß der nach dem Bilde Gottes erschaffene Mensch so tief sinken und verwildern könnte!" [who would have thought it possible that man, created in God's image, could sink to such low depths, and could become so wild?; 36]. Clearly, as late as 1801, war was still incompatible with Becker's Enlightenment philosophy, and there was very little space for narrow-minded nationalism in his egalitarian worldview. But did Becker adapt his stance in response to the increasing militarisation and nationalisation of his reading public during the next fifteen years, including the Wars of Liberation?

\section{<L1> After the Wars: Mildheimisches Liederbuch (1815) and Becker's Prison Memoir}

Schneider has pointed out that the 1815 edition of Mildheimisches Liederbuch contains reams of political songs produced in support of the nationalist movement during the Wars of Liberation (Schneider 291, note 2). He also draws attention to the introduction of two new sections, whose titles reveal the newly increased significance of military songs and celebrations by this time: "Für Soldaten, Landwehr und Landsturmmänner" [for soldiers and reserves] and "Lieder zum Fest aller Deutschen, den 18. und 19. October" [songs for the festival of all Germans on 18 and 19 October; Schneider 303]. By identifying key themes, and counting the number of songs in both editions which address them, Schneider reveals certain shifts that had taken place in the public consciousness during Germany's period of Napoleonic rule, especially regarding nationalism and the military. The number of songs glorifying death for the fatherland jumps from three (in the first edition) to thirteen; on the topic of soldiers in general from three to sixteen; and on the enmity of the French from three to eleven. Other ideas have also gained prominence in reaction to the French Revolutionary wars. For instance, the religious notion of reliance on God now takes up thirteen songs, rather than only two; and sentiments such as praise for the princes, criticism of tyrants, and freedom and human rights are more numerously represented in 1815 than they were in 1799 . Yet we 
might well ask why Becker chose to include so much of this material, especially when some of the more violent and aggressive material contradicted his own moral theories of perfectibility and Enlightenment progress. Having gone to such lengths in 1799 to select only texts which suited his Enlightenment philosophy of perfectibility, why include so much popular material now? The inclusion of so much poetry in support of the Wars of Liberation in the second edition of Mildheimisches Liederbuch indicates that something significant about Becker's editorial attitude had changed between 1799 and 1815. It seems to show him relaxing his control over his material, allowing more, and conflicting, political voices to be heard.

I explain this change in Becker's editorial practice as his reaction to the harsh censorship Germany had experienced under French rule. As a publisher, Becker had always been firmly against controlling freedom of speech, but his aversion to this aspect of Napoleon's rule was further strengthened when he was imprisoned for seventeen months in Magdeburg fortress in light of publications which Napoleon perceived as a threat to his regime (see Tölle 93-114, 223; Freytag 57-59). A year after his release on 5 May 1813, Becker began working on a personal memoir of his experiences, entitled Leiden und Freuden in siebzehnmonatlicher Gefangenschaft [sufferings and joys over seventeen months in prison]. In this memoir, he maintains his role as the morally upstanding Enlightenment writer, presenting his time in captivity as having strengthened his religious faith (Leiden 192), as well as having taught him the importance of tolerance.

Significantly, Becker's memoir never incites hatred of the French, nor encourages the reader to take up arms. Again and again, Becker writes in defense of the French prison guards and officials that he met with, "um nicht den Nationalhaß gegen ein Volk zu nähren, das die ihm eigenthümlichen Fehler des Charackters durch so manche Vorzüge in der geistigen und geselligen Bildung vergütet" [so as not to feed the national hatred of a people who quite 
make up for their unique character flaws through their many intellectual and social merits and achievements; Leiden 182]. Becker's only real bone to pick with the French, he argues, is Napoleon's despotism. For a despotic state can only be maintained by oppressive structures which must stand in direct contradiction to God's plan for humanity (that is, for constant development and self improvement). Only states ruled by "erbliche monarchische Verfassung[en]" (inherited constitutional monarchies) can allow their subordinates to achieve this kind of self-fulfilment, he argues. In despotic states, on the contrary, all subordinates become mere pawns in the ruler's games, having no will or rights of their own (Leiden 1823). The despotic state is diametrically opposed to the kind of self-governed society for which Becker's Volksaufklärung programme had argued, in which people are encouraged to think for themselves, and to take action to improve their own communities for the common good. Toppling the tyrant Napoleon was therefore in the mutual interest of both the French and the Germans:

[Es ist nötig] daß wir den letzten Blutstropfen daran setzen, die hohen Zwecke des jetzigen Völkerkrieges $\mathrm{zu}$ erringen: Freyheit und Selbstständigkeit dem Vaterlande, und die Rechte der Menschheit allen Völkern Europas, auch - dem französischen.

[We must fight to the last drop of blood to achieve the noble goals of the current civil war: freedom and independence for the fatherland, and human rights for all people of Europe, including the French; Leiden und Freuden 192.]

Fittingly, his memoir therefore ends with a poem thanking God for Germany's liberation (seeing it as stemming from God's will, rather than attributing it to German military superiority), and calling now for forgiveness and mercy between the two countries:

Groll und Rache sey vergessen; 
Unserm Todfeind sey verziehn!

Keine Thräne soll ihn pressen,

Keine Reue nage ihn!

Unser Schuldbuch sey vernichtet,

Ausgesöhnt die ganze Welt!

Droben überm Sternenzelt

Richtet Gott, wie wir gerichtet.

[May resentments and vengeance now be forgotten, may our enemy be forgiven! No more tears shall oppress him, nor regrets burden him. May all debts be called off, and all the world be reconciled! High above the firmament, God will judge how we have judged; Leiden und Freuden 196]

In his own poems and writings, therefore, Becker does not express nationalistic, anti-French sentiments, rather maintaining that it is in everyone's interest to topple Napoleon, in order to restore peace and freedom for all. Some of the poetry in support of the Wars of Liberation included in the 1815 edition of Mildheimisches Liederbuch, however, contains sentiments which flatly contradict these peaceful hopes. For instance, Arndt's famous poem "Was ist des Deutschen Vaterland" [What is the German Fatherland?] included as song 563, defines Germanness as a shared hatred of the French: "Das ist das deutsche Vaterland, [...], wo jeder Franzmann heißet Feind" [the German fatherland is wherever the French are hated; MLB.2 361]. A text from the first volume of Des Knaben Wunderhorn (called "Husarenglaube"), with its violent imagery of decapitating French soldiers, also appears in this edition as song 758. Immediately after this song comes another, even more violent one. One verse will serve to show its general theme: 
Was willst du, Franzos, an des Rheines Gestaden? Willst unsere Schiff für dich wohl entladen? Du Räuber, wir wollen dir füllen den Sack, statt köstlicher Waare, mit blutigem Pack!

[What do you want, Frenchman, on the banks of the Rhine? Do you want to empty our ships for yourself? You thief, we will not fill your bags with precious wares, but with bloody ones!; MLB.2 504.]

The inclusion in 1815 of a wider variety of material, expressing viewpoints which Becker did not personally share, shows that he has modified his editorial role. While Becker's 1799 collection had employed a very controlling editorial approach, even though he did not personally pen most of the texts in the collection, his editorial method in 1815 opens the work up to more diverse messages. He no longer feels a need to disguise the work as an anonymous, collectively authored Volksschrift (chapbook), and instead names all of the contributors in the collection. The work becomes polyphonic, revealing a more democratic, rather than authoritarian attitude to pedagogy. I see this new openness and tolerance in Becker's approach as a response to Napoleon's authoritarian censorship and surveillance (“die lauernden Klapperschlangen der Pariser hohen Polizey" [those lurking rattlesnakes from the French high police]; Leiden 119), as well as his own experiences of political imprisonment. Rather than censoring material and maintaining a sense of pedagogic authority, Becker's 1815 edition instead models a more trusting form of education.

That his time in prison had a profound effect on Becker's outlook is shown not only by his prison memoir, but also in the only new poem that he contributed personally to Mildheimisches Liederbuch in 1815: song 243. After its attribution to Becker, the poem carries the footnote: "Den 13. Febr. 1812 in der Casematte Nr. IV. auf der Citadelle zu Magdeburg auf Birkenrinde geschrieben" [written on 13 February in casemate no. 4 in Magdeburg fortress, on a piece of birch bark; MLB.2 148], thus overtly inviting a 
biographical reading of this poem. It bears striking similarities to another poem by Schubart on the same theme, called "Der Gefangene" [the prisoner], which also precedes it in the collection. Schubart's poem is similarly adorned with a footnote and biographical reference: “Auf der würtembergischen Bergstellung Hohenasperg verfaßt, wo der Dichter viele Jahre seines Lebens gefangen saß, ohne zu wissen, warum" [written in the Württemberg mountain fortress of Hohenasperg, where the poet sat imprisoned for many years, without knowing the reason; MLB.2 147]. This parallel presentation draws an association between Becker and Schubart, presenting both as defiant agitators, willing to suffer physically for their political beliefs. Schubart's poem was not included in the 1799 version of Mildheimisches Liederbuch, and so Becker's decision to print it in 1815 suggests it now held a special importance for him. Becker's poem copies the form of Schubart's exactly, and there are also parallels in content. Both texts have eleven stanzas, each of four cross-rhymed lines, yet the message of Becker's poem contrasts significantly with that of Schubart's. The tone of the latter is desperate and hopeless, with the repeated refrain of "Gefangener Mann-ein armer Mann!" [imprisoned man—a poor man!] whereas Becker's poem applies his trademark optimism, faith, and hope, even to this direst of situations. The closing lines of Becker's poem stress the importance of a reliance on God, which can bring joy and freedom, even in death, and present Becker himself as a (potential) martyr for his political cause — an idea also seen in his prison memoir (Leiden 25). However, Becker's (imagined) death here is the death of the political prisoner, rather than that of the soldier. Becker and Schubart are depicted as patriotic martyrs for their own consciences here. Patriotism for Becker is not simply a matter of fighting and dying for a collective defined by its allegiance to a political leader. Rather, what matters are the higher values for which each individual is willing to suffer, and not necessarily on the battlefield.

$<$ L1 $>$ Conclusion 
Overall, then, we have seen how Becker's two editions of Mildheimisches Liederbuch reveal the fraught complexity of the discourses around war and nationalism both in 1799 and 1815 . I have argued that Becker maintained his own moral stance against war and nationalism, even after experiencing political oppression of the harshest kind. However, Becker allowed his collection to include some violent, nationalistic viewpoints that he did not personally appear to share, and this suggests that his commitment to freedom of expression ultimately overruled his desire to select, censor, and shape his material to reflect his own personal beliefs. What had begun as an educational songbook for peasants in 1799 takes the shape, in 1815, of a poetic anthology for the whole reading and singing public. Rather than enforcing the first edition's pedagogical aims for Enlightenment progress based on Becker's individual philosophy of Enlightenment, the second edition reflects the competing thoughts and emotions experienced by a nation emerging from occupation. His inclusion of so many nationalistic and militaristic songs should not be seen as evidence that Becker, or the German nation as a whole, had been brainwashed by such material. On the contrary, I suggest that it shows Becker experimenting with a new educational method in this 1815 edition: one founded not on pedagogical authoritarianism, but on tolerance and trust. Rather than spoonfeeding his readers a diet of pure, Enlightened moral fibre, we might see Becker's second edition of Mildheimisches Liederbuch as more truly Enlightened, in that it contains conflicting narratives around war, patriotism, and nationalism, and therefore allows readers to think for themselves. More importantly, its inclusion of genuinely popular material allowed it to represent the developing German nation in a manner befitting an Enlightened, more democratically oriented society—something Becker was still hoping to achieve, though this was still a long time coming. 


\section{Works Cited}

Primary

Becker, Rudolph Zacharias. “An die Leser.” Deutsche Zeitung für die Jugend und ihre Freunde, oder moralische Schilderungen der Menschen, Sitten und Staaten unsrer Zeit, vol. 49, 7 December 1787, pp. 403-10.

---. Das Friedensfest, wie solches zu Mildheim gefeyert worden : nebst der Vorlesung des Korporal Wackersinn vom Soldatenleben und Kriegswesen und der Predigt vom ewigen Frieden, welche der Herr Pfarrer Starke auf dem Luftplatze gehalten. Beckersche Buchhandlung, 1801.

---. Fragebuch für Lehrer über das Noth- und Hülfsbüchlein. Beckersche Buchhandlung, 1799.

---. Leiden und Freuden in siebzehn monatlicher französischer Gefangenschaft: Von ihm selbst beschrieben. Beckersche Buchhandlung, 1814.

---. Mildheimisches Liederbuch: Faksimiledruck nach der Ausgabe von 1815. Edited by Günter Häntzschel, Metzler, 1971.

---. Mildheimisches Liederbuch von 518 lustigen und ernsthaften Gesängen, über alle Dinge in der Welt und alle Umstände des menschlichen Lebens, die man besingen kann. Beckersche Buchhandlung, 1799.

---. Noth- und Hülfsbüchlein für Bauersleute: Nachdruck der Erstausgabe von 1788. Edited by Reinhart Siegert, Harenberg, 1980.

---. Noth- und Hülfs-Büchlein oder lehrreiche Freuden- und Trauer-Geschichte der Einwohner zu Mildheim: Zweiter Theil. Beckersche Buchhandlung, 1798.

---. "Versuch über die Aufklärung des Landmannes." Der Teutsche Merkur, vol. 3, 1785, pp. $108-31$. 
Hiller, Johann Adam, et al. Der Krieg: Eine komische Oper in drei Akten. 1773.

http://digital.staatsbibliothekberlin.de/werkansicht?PPN=PPN72988418X\&P HYSID=PHYS_0009\&DMDID=.

Kant, Immanuel. “Zum ewigen Frieden: Ein philosophischer Entwurf.” Immanuel Kants Werke. Edited by A. Buchenau, E. Cassirer, and B. Kellermann, vol. 6, Cassirer, 1923, pp. 425-74.

Schubart, Christian Friedrich Daniel. Schubarts Werke in einem Band. Edited by Ursula Wertheim and Hans Böhm, Volksverlag, 1959.

Secondary

Becker, Ernst Wolfgang. Zeit der Revolution! - Revolution der Zeit? Zeiterfahrungen in Deutschland in der Ära der Revolutionen 1789-1848/49. Vandenhoeck \& Ruprecht, 1999.

Birgfeld, Johannes. Krieg und Aufklärung: Studien zum Kriegsdiskurs in der deutschsprachigen Literatur des 18. Jahrhunderts. Wehrhahn, 2012, 2 vols.

Blitz, Hans-Martin. Aus Liebe zum Vaterland: Die deutsche Nation im 18. Jahrhundert. Hamburger Edition, 2000.

Böning, Holger, et al., editors. Volksaufklärung: Eine praktische Reformbewegung des 18. und 19. Jahrhunderts. Lumière, 2007.

Freytag, Christine. "Mensch, werde und mache alles immer besser": Überlegungen zur Aufklärung und Vervollkommnung des Menschen am Beispiel von Rudolph Zacharias Becker in der Zeit von 1779 bis 1794. Edition Paideia, 2014.

Grätz, Katharina. "Enttäuschte Erwartungen. Schubarts Lyrik zwischen Rollenspiel und authentischen Selbstausdruck." Christian Friedrich Daniel Schubart: Das Werk, edited by Barbara Potthast, Winter, 2016, pp. 299-320. 
Harari, Yuval Noah. The Ultimate Experience: Battlefield Revelations and the Making of Modern War Culture, 1450-2000. Palgrave Macmillan, 2008.

Joubert, Estelle. "Songs to Shape a German Nation: Hiller's Comic Operas and the Public Sphere.” Eighteenth-Century Music, vol. 3, no. 2, 2006, pp. 213-30.

Pilsworth, Ellen. “'Nicht unsrer Lesewelt, und nicht der Ewigkeit”: Late Style in Gleim's Zeit- and Sinngedichte (1792-1803)," Edinburgh German Yearbook 12: RePopulating the Eighteenth Century: Second-Tier Writing in the German Enlightenment, edited by Johannes Birgfeld and Michael Wood. Camden House, 2018, pp. 52-68.

Scarry, Elaine. The Body in Pain: The Making and Unmaking of the World. Oxford UP, 1985.

Schneider, Herbert. "Revolutionäre Lieder und vaterländische Gesänge: Zur Publikation französischer Revolutionslieder in Deutschland und zum politischen Lied in R. Z. Beckers Mildheimischem Liederbuch.” Volk - Nation - Vaterland, edited by Ulrich Herrmann, Felix Meiner, 1996, pp. 291-324.

Siegert, Reinhart. Aufklärung und Volkslektüre: Exemplarisch dargestellt an Rudolph Zacharias Becker und seinem "Noth- und Hülfsbüchlein": mit einer Bibliographie zum Gesamtthema. Buchhändler-Vereinigung, 1978.

Steinitz, Wolfgang. Deutsche Volkslieder demokratischen Charakters aus sechs Jahrhunderten, vol. 1, Akademie, 1962.

Tölle, Ursula. Rudolph Zacharias Becker: Versuche der Volksaufklärung im 18. Jahrhundert in Deutschland. Waxmann, 1994.

Weber, Ernst. Lyrik der Befreiungskriege (1812-1815). Gesellschaftspolitische Meinungsund Willensbildung durch Literatur. Metzler, 1991. 
Weissert, Gottfried. Das Mildheimische Liederbuch: Studien zur volkspädagogischen Literatur der Aufklärung. Horst Bissinger, 1966.

Wilson, W. Daniel. “Skeletons in Goethe's Closet: Human Rights, Protest, and the Myth of Political Liberality.” Unwrapping Goethe's Weimar: Essays in Cultural Studies and Local Knowledge, edited by Burkhard Henke, Susanne Kord, and Simon Richter, Camden House, 1999, pp. 295-309.

Wirtz, Michaela. Patriotismus und Weltbürgertum: Eine begriffsgeschichtliche Studie zur deutsch-jüdischen Literatur 1750-1850. Niemeyer, 2006. 